\title{
Upaya Meningkatkan Kemampuan Perencanaan Karier Melalui Layanan Informasi Karier pada Saat Pandemi Covid-19 bagi Siswa di SMA Negeri 2 Praya
}

\author{
Ni Nyoman Danti \\ SMA Negeri 2 Praya, Kabupaten Lombok Tengah - Provinsi NTB \\ Corresponding Author. Email: nyomandanti68@gmail.com
}

\begin{abstract}
The purpose of this study was to improve career planning skills through career information services during the Covid-19 pandemic for class XII-MIA-1 students of SMA Negeri 2 Praya in the academic year 2020/2021. This research method uses a classroom action research method consisting of 2 cycles of action. The research instrument used observation sheets and tests. The data analysis technique used descriptive analysis. Based on the results of the data analysis of the implementation of the action in cycle I, it shows that the percentage of students' career planning abilities is very high as many as 4 people or $11.76 \%$, high career planning abilities are 5 people or $14.71 \%$, while as many as 8 people or $23.53 \%$, low 8 people amounted to $23.53 \%$ and very low category career planning ability 9 people or $26.47 \%$. Based on the results of cycle II analysis, it was found that students had very high career planning abilities as many as 12 people or $35.29 \% \%$, high career planning abilities by 9 people or $26.47 \%$ and career planning abilities in the medium category of 7 people or $20.59 \%$, low career planning ability as many as 4 people or $11.76 \%$, and very low career planning ability as many as 2 people or $5.88 \%$.
\end{abstract}

\begin{abstract}
Abstrak: Tujuan penelitian ini adalah untuk meningkatkan kemampuan perencanaan karier melalui layanan informasi karier pada saat pandemi Covid19 bagi siswa kelas XII-MIA-1 SMA Negeri 2 Praya Tahun Pelajaran 2020/2021. Metode penelitian ini menggunakan metode penelitian tindakan kelas yang terdiri dari 2 siklus tindakan. Instrumen penelitian ini menggunakan lembar observasi dan tes. Teknik analisis datanya menggunakan analisis deskriptif. Berdasarkan hasil analisis data pelaksanaan tindakan pada siklus I menunjukkan bahwa prosentase kemampuan perencanaan karier kategori siswa sangat tinggi sebanyak 4 orang atau $11,76 \%$, kemampuan perencanaan karier tinggi sebanyak 5 orang atau $14,71 \%$, sedangkan sebanyak 8 orang atau $23,53 \%$, rendah 8 orang sebesar $23,53 \%$ dan kemampuan perencanaan karier kategori sangat rendah 9 orang atau 26,47\%. Berdasarkan hasil analisis siklus II diperoleh siswa memiliki kemampuan perencanaan karier sangat tinggi sebanyak 12 orang atau $35,29 \% \%$, kemampuan perencanaan karier tinggi sebesar 9 orang atau $26,47 \%$ dan kemampuan perencanaan karier kategori sedang sebesar 7 orang atau 20,59\%, kemampuan perencanaan karier rendah sebanyak 4 orang atau $11,76 \%$, dan kemampuan perencanaan karier sangat rendah sebanyak 2 orang atau 5,88\%.
\end{abstract}

Article History

Received: 10-02-2021

Revised: 10-03-2021

Published: 04-04-2021

Key Words:

Career Planning, Information

Services.

\author{
Sejarah Artikel \\ Diterima: 10-02-2021 \\ Direvisi: 10-03-2021 \\ Diterbitkan: 04-04-2021
}

\section{Kata Kunci:}

Perencanaan Karier, Layanan Informasi.

How to Cite: Danti, N. (2021). Upaya Meningkatkan Kemampuan Perencanaan Karier Melalui Layanan Informasi Karier pada Saat Pandemi Covid-19 bagi Siswa di SMA Negeri 2 Praya. Jurnal Paedagogy, 8(2). doi:https://doi.org/10.33394/jp.v8i2.3498

d. https://doi.org/10.33394/jp.v8i2.3498

This is an open-access article under the CC-BY-SA License.

\section{Pendahuluan}

Karier seringkali disamakan dengan pekerjaan. Perencanaan karier disamakan dengan pemilihan pekerjaan. Sebenarnya arti karier lebih luas dari sekedar memilih pekerjaan. Karier berkaitan dengan perkembangan seseorang dan menjadi bagian penting dalam kesuksesan hidup seseorang, untuk itu karier perlu direncanakan dengan baik. Kemampuan perencanaan 
karier yang matang erat kaitannya dengan pemahaman siswa mengenai karier itu sendiri (Ifdil, 2011).

Suksesnya pencapaian karier seseorang dipengaruhi oleh adanya kemampuan perencanaan karier dan pengambilan keputusan yang matang. Seseorang yang memiliki kemampuan perencanaan karier, tentunya mampu memahami dirinya. Dengan demikian, individu tersebut dapat memutuskan pilihan yang paling tepat sesuai dengan keadaan dirinya. Masa remaja adalah masa peralihan dari anak-anak ke dewasa. Sebagai individu yang sedang mengalami proses peralihan, remaja memiliki tugas-tugas perkembangan yang mengarah pada kesiapannya memenuhi tuntutan dan harapan peran sebagai orang dewasa. Orientasi masa depan atau karier merupakan salah satu fenomena perkembangan kognitif yang terjadi pada masa remaja. Seperti yang dikemukakan oleh Hurlock (2012), "remaja mulai memikirkan tentang masa depan mereka secara sungguh-sungguh". Siswa yang duduk dibangku SMA atau SMK sudah mulai merencanakan masa depan atau karier yang sesuai dengan yang mereka harapkan sebelum mereka benar-benar menginjak dunia kerja (lulus SMA atau SMK). Menurut teori perkembangan Ginzberg (dalam Munandir, 1996) menyebutkan bahwa "siswa SMA atau SMK berada pada masa tentatif di mana siswa harus sudah mampu memikirkan atau merencanakan karier mereka berdasarkan minat, kapasitas atau kemampuan, dan nilai-nilai atau potensi yang mereka miliki”. Beberapa siswa merencanakan kariernya secara tidak realistis. Mereka membuat rencana karier hanya didasarkan atas kemauan dan keinginannya tanpa mempertimbangkan kemampuan yang dimiliki. Bahkan ada di antara siswa yang menyerahkan pilihan kariernya pada teman sebaya atau orang lain. (Ummah, 2013; Suryani \& Gunawan, 2018).

Berdasarkan hasil studi pendahuluan wawancara dengan siswa kelas XII MIA-1 SMA Negeri 2 Praya Lombok Tengah, diperoleh informasi bahwa materi yang disampaikan oleh konselor atau guru umum dalam pemberian layanan di kelas membahas tentang pengenalan bimbingan konseling dan pribadi siswa, sedangkan materi yang membahas tentang karier jarang disampaikan oleh terhadap siswa di kelas. Meskipun pada saat pandemi Covid-19 seperti ini siswa mendatangi konselor yang berada di Bimbingan Konseling Karier (BKK) dengan mematuhi protokol kesehatan bertanya perihal karier apabila tamat sekolah nanti. Siswa kelas XII lebih aktif mencari informasi tentang karier karena sudah mulai merencanakan kariernya. Ketika ditanya mereka masih bingung dan belum mempunyai rencana akan melanjutkan studi atau bekerja di mana setelah lulus dari SMA.

Pencanaan karier pada saat pandemi Covid-19 perlu dijelaskan dengan mematuhi protokol kesehatan. Virus Corona adalah bagian dari keluarga virus yang menyebabkan penyakit pada hewan ataupun juga pada manusia. Di Indonesia, masih melawan Virus Corona hingga saat ini, begitupun juga di negara-negara lain. Jumlah kasus Virus Corona terus bertambah dengan beberapa melaporkan kesembuhan, tapi tidak sedikit yang meninggal. Usaha penanganan dan pencegahan terus dilakukan demi melawan Covid-19 dengan gejala mirip Flu. Saat Covid-19 pun peserta didik memerlukan informasi tentang dunia kerja dan konsep diri terlihat pada tahap eksplorasi umumnya remaja mulai menerapkan pilihan-pilihan yang dipikirkan pada tahap tentatif akhir. Mereka menimbang-nimbang beberapa kemungkinan pekerjaan yang mereka anggap sesuai dengan bakat, minat, serta nilai-nilai mereka, namun mereka belum berani mengambil keputusan tentang pekerjaan mana yang paling tepat. Sedangkan bakat dan minat adalah bagian dari konsep diri dari para siswa. Dan juga informasi tentang dunia kerja yang mereka peroleh dari berbagai media dan presentasi dari berbagai pihak yang menceritakan tentang dunia kerja. Layanan informasi karier merupakan salah satu usaha membantu siswa dalam membuat perencanaan karier di mana 
layanan informasi karier berisi tentang informasi-informasi yang berhubungan dengan karier siswa, maka sangat tepat bila digunakan dalam meningkatkan kemampuan perencanaan karier siswa.

Adapun tujuan penelitian ini adalah untuk meningkatkan kemampuan perencanaan karier melalui layanan informasi karier pada saat pandemi Covid-19 bagi siswa kelas XIIMIA-1 SMA Negeri 2 Praya Tahun Pelajaran 2020/2021.

\section{Metode Penelitian}

Pelaksanaan penelitian ini menggunakan metode penelitian tindakan kelas (PTK). Adapun tahapan pelaksanaan PTK ini meliputi 4 (empat) langkah pokok yaitu : perencanaan, implementasi, observasi, dan evaluasi serta refleksi. Subjek penelitian ini adalah semua siswa kelas XII- MIA-1 yang berjumlah 34 orang yang terdiri dari 17 orang siswa laki-laki dan 17 orang perempuan. Teknik pengumpulan data penelitian ini terdiri dari; (1) Data aktivitas guru dalam kelas diambil menggunakan lembar observasi yang berbentuk (check list)/ angka pada setiap akhir siklus. (2) Data aktivitas siswa selama proses layanan informasi karier pada saat pandemi Covid-19 berlangsung diambil dengan menggunakan lembar observasi yang berupa "aktivity check list"/ angka pada setiap siklus. (3) Data jurnal persepsi siswa terhadap proses perencanaan karier melalui layanan informasi karier. (4) Data hasil belajar diperoleh dengan menggunakan tes dalam bentuk isian/ pilihan ganda yang telah disiapkan pada setiap akhir siklus. Teknik analisis data yang digunakan dalam penelitian ini adalah analisis data deskriptif. Penelitian ini dikatakan berhasil jika terjadi peningkatan perencanaan karier siswa. Perencanaan karier siswa dikatakan meningkat apabila prosentase mencapai $\geq 85 \%$. Layanan karier dikatakan meningkat apabila perencanaan karier minimal berkatagori aktif.

\section{Hasil Penelitian dan Pembahasan}

\section{Pelaksanaan Layanan Informasi Karier Siklus 1}

Siklus pertama dilaksanakan selama tiga kali yaitu bulan Agustus-September 2020. Dalam pertemuan tersebut dilaksanakan layanan informasi karier secara klasikal dan maksimal. Evaluasi untuk mengukur hasil kemampuan perencanaan karier masa pandemi Covid-19 di kelas XII-MIA-1 SMA Negeri 2 Praya Kabupaten Lombok Tengah dipersiapkan secara matang. Pada siklus ini materi yang dibahas adalah pemahaman diri, mengenali bakat dan minat, cita-citaku. Berdasarkan hasil diagnosis kondisi awal, maka peneliti bersama masukan kolabolator memberikan tindakan kepada siswa yang tergolong memiliki kemampuan perencanaan karier rendah dan beberapa siswa yang memiliki kemampuan perencanaan karier diberikan batuan berupa layanan informasi karier. Pemberian tindakan diberikan sebanyak dua siklus terhadap partisipan/ responden yang berjumlah 34 siswa. Teknik pelaksanaan layanan informasi karier saat pandemi Covid-19 terdiri dari perencanaan (Planning), tindakan (Action), pengamatan (Observation), refleksi (Reflection). Untuk mengetahui kemampuan perencanaan karier dan hasil dari layanan informasi karier pada siswa digunakan alat bantu berupa instrumen skala psikologi, wawancara, dan observasi. Dari tahapan-tahapan siklus 1 tersebut dapat dijelaskan secara jelas, sebagai berikut:

\section{Perencanaan}

Peneliti bersama kolaborator merencanakan pemberian tindakan berupa layanan informasi karier pada siklus 1 dengan tujuan untuk meningkatkan kemampuan perencanaan karier pada saat pandemi Covid-19 pada siswa kelas XII-MIA-1 SMA Negeri 2 Praya 
Lombok Tengah. Perencanaan ini bertujuan agar proses pelaksanaan tindakan berjalan dengan lancar dan sesuai harapan.

\section{Pelaksanaan Tindakan}

Penelitian tindakan ini dilaksanakan sebanyak tiga kali pertemuan pada setiap siklusnya. Peneliti melaksanakan rencana tindakan layanan informasi karier sesuai prosedur dan perencanaan yang dilakukan oleh peneliti dan kolaborator.

\section{Observasi}

Pada saat kegiatan layanan informasi karier saat pandemi Covid-19 observer mengamati aktivitas guru dalam memberikan layanan informasi karier pada kelas XII-MIA-1. Data aktivitas guru dalam melaksanakan kegiatan layanan informasi karier diperoleh dengan menggunakan lembar observasi aktivitas guru dalam memberikan layanan informasi karier yang dibantu oleh observer. Skor aktivitas guru dalam kegiatan layanan informasi karier pada siklus I sebesar 12, diperoleh dari jumlah skor setiap indikator. Berdasarkan kriteria aktivitas guru yang tercantum pada bab III maka aktivitas guru pada siklus I dapat dikategorikan baik, karena terletak pada interval $11 \leq \mathrm{A}_{\mathrm{g}}<15$. Guru telah melakukan semua indikator dan deskriptor yang sudah ditentukan. Kegiatan guru dalam mempersiapkan rencana kegiatan layanan informasi karier sudah tergolong baik, hanya saja pelaksanaan setiap kegiatan layanan informasi karier yang dilakukan oleh guru belum maksimal dan perlu ditingkatkan lagi. Selama proses kegiatan layanan informasi karier pada siklus I terdapat kekurangan pada aktivitas guru kegiatan layanan informasi karier yang perlu mendapatkan tindakan perbaikan pada siklus selanjutnya. Berdasarkan analisis hasil observasi aktivitas siswa dalam kegiatan layanan informasi karier terhadap indikator yang ditetapkan terdapat tiga indikator yang belum maksimal dilakukan oleh sebagian besar siswa yaitu interaksi siswa dengan guru dan partisipasi siswa dalam kegiatan layanan informasi karier. Skor aktivitas siswa dalam mengikuti kegiatan layanan informasi karier pada saat pandemi Covid-19 siklus I sebesar 47, diperoleh dari jumlah skor pada setiap indikator. Berdasarkan kriteria aktivitas siswa maka aktivitas siswa pada siklus I dapat dikategorikan aktif, karena terletak berada pada interval $41 \leq \mathrm{A}_{\mathrm{s}}<60$.

\section{Hasil Evaluasi kegiatan layanan informasi karier pada saat pandemi Covid-19}

Evaluasi kegiatan bimbingan layanan informasi karier pada saat pandemi Covid-19 dilaksanakan untuk mengukur sejauh mana kemampuan siswa perencanaan karier pada siklus I. Selanjutnya hasil rekapitulasi hasil instrument kegiatan kemampuan perencanaan karier siklus I dapat digambarkan dalam diagram berikut.

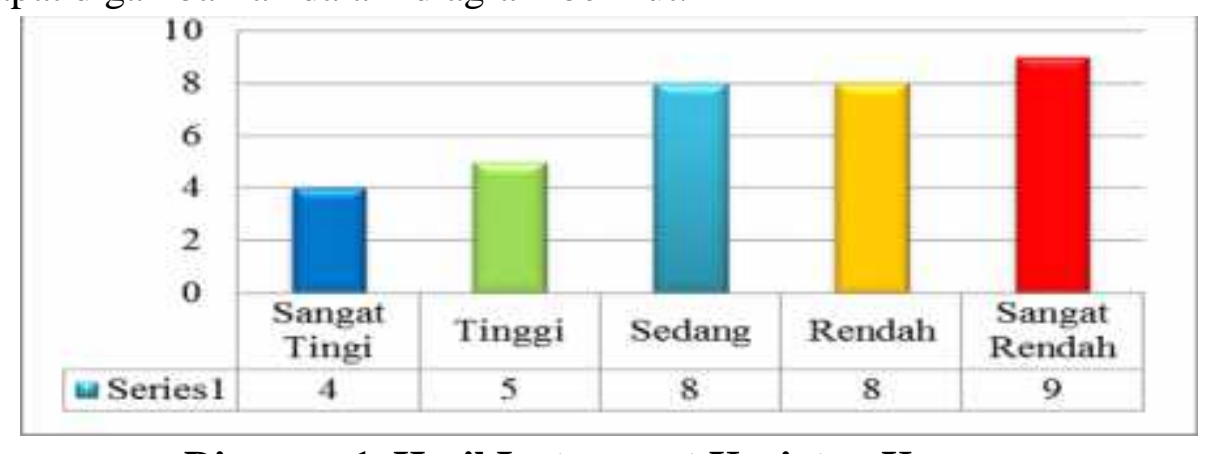

Diagram 1. Hasil Instrument Kegiatan Kemampuan

Perencanaan Karier pada Saat Pandemi Covid-19 Siklus I

Berdasarkan gambar diagram batang di atas dimaknai bahwa siswa memiliki kemampuan perencanaan karier pada siklus 1 sebagai berikut, siswa berkemampuan perencanaan karier terdiri dari 4 orang atau $11,76 \%$, siswa memiliki kemampuan perencanaan karier tinggi terdiri 
dari 5 orang atau $14,71 \%$, siswa memiliki kemampuan perencanaan karier sedang sebanyak 8 orang $23,53 \%$, siswa memiliki kemampuan perencanaan karier rendah sebanyak 8 orang atau 23,53\% dan siswa memiliki disiplin belajar sangat rendah sebanyak 9 orang atau 26,47\%.

\section{Pelaksanaan Layanan Informasi Karier Siklus 2}

Siklus 2 dalam penelitian ini memberikan tindakan yaitu layanan informasi karier lanjutan dan bertujuan untuk menyempurnakan hasil perencanaan karier siklus 1 . Perbedaan siklus 1 dan siklus 2 terletak pada pemantapan teknik layanan. Jika pada siklus 1 menggunakan pendekatan secara klasikal, maka pada siklus 2 ini menggunakan teknik individu sesuai pilihan karier yang direncanakan dengan topik layanan informasi karier. Siklus 2 dalam penelitian ini merupakan perbaikan atau penyempurnaan dari siklus 1 yang belum dijalankan secara maksimal oleh peneliti. Hasil perbaikan pelaksanaan tindakan pada siklus 2 dilaksanakan dalam 4 tahap yaitu tahap perencanaan, tindakan, pengamatan, dan refleksi. Berikut dipaparkan masing-masing tahapannya.

\section{Perencanaan}

Sebelum memulai tindakan pada siklus 2, peneliti terlebih dahulu membuat perencanaan kembali agar tindakan yang dilakukan peneliti pada siklus 2 dapat berjalan dengan baik dan sesuai dengan tujuan penelitian dan memperoleh hasil maksimal.

\section{Pelaksanaan Tindakan}

Pada tahap tindakan ini, peneliti melaksanakan tindakan layanan informasi karier sesuai dengan tahapan layanan informasi karier yang direncanakan lebih rinci. Tahap tindakan pada siklus 2 ini dilaksanakan sebanyak empat kali pertemuan. Masing-masing pertemuan dilakukan satu kali layanan informasi karier dengan topik pengaruh keluarga terhadap perencanaan karier pada saat pandemi Covid-19.

\section{Pengamatan}

Pengamatan dilakukan untuk mengetahui sejauh mana tindakan layanan informasi karier dapat berjalan dengan baik. Tahap ini dilakukan pengamatan proses dan hasil dari pemberian tindakan layanan informasi karier. Selain itu, tahap ini juga dilakukan peneliti sebagai tindak lanjut dari proses layanan informasi karier yang telah selesai dilakukan. Pada tahap ini, peneliti melakukan pengamatan terhadap siswa selama mengikuti layanan informasi karier secara keseluruhan. Data aktivitas guru dalam melaksanakan kegiatan layanan informasi karier diperoleh dengan menggunakan lembar observasi aktivitas guru dalam layanan informasi karier yang dibantu oleh observer/ kolaborator. Skor aktivitas guru kegiatan layanan informasi karier pada siklus II sebesar 13, diperoleh dari jumlah skor pada setiap indikator. Berdasarkan kriteria aktivitas guru yang tercantum pada bab III maka aktivitas guru kegiatan layanan informasi karier pada siklus II dapat dikategorikan baik, karena terletak pada interval $11 \leq \mathrm{A}_{\mathrm{g}}<15$. Guru telah melakukan semua indikator dan deskriptor yang sudah ditentukan. Kegiatan guru dalam mempersiapkan rencana kegiatan layanan informasi karier sudah tergolong baik, hanya saja pelaksanaan setiap kegiatan layanan informasi karier yang dilakukan oleh guru perlu ditingkatkan lagi secara maksimal. Selama proses kegiatan layanan informasi karier pada siklus II aktivitas guru kegiatan layanan informasi karier pada saat pandemi Covid-19 sudah mengalami peningkatan yang cukup baik. Selama proses kegiatan layanan informasi karier yang telah dilakukan pada siklus II terdapat kelebihan-kelebihan yang harus dipertahankan dan ditingkatkan. Berdasarkan analisis hasil observasi aktivitas siswa dalam kegiatan layanan informasi karier siklus II semua indikator sudah dilakukan sesuai program layanan dan harapan guru. Skor aktivitas siswa dalam kegiatan layanan informasi karier pada siklus II sebesar 53, diperoleh dari jumlah skor pada setiap indikator. Berdasarkan kriteria aktivitas siswa, maka aktivitas 
siswa dalam menerima layanan informasi karier pada siklus II dapat dikategorikan sangat aktif, karena terletak berada pada interval $41 \leq \mathrm{A}_{\mathrm{s}}<60$.

\section{Hasil Evaluasi kegiatan layanan informasi karier}

Evaluasi kegiatan layanan informasi karier pada saat pandemi Covid-19 dilaksanakan untuk mengukur sejauh mana kemampuan merencanakan karier atau daya seraf siswa dalam memahami materi kegiatan layanan informasi karier pada siklus II. Selanjutnya hasil rekapitulasi hasil instrument kegiatan layanan informasi karier siklus II dapat digambarkan dalam diagram berikut.

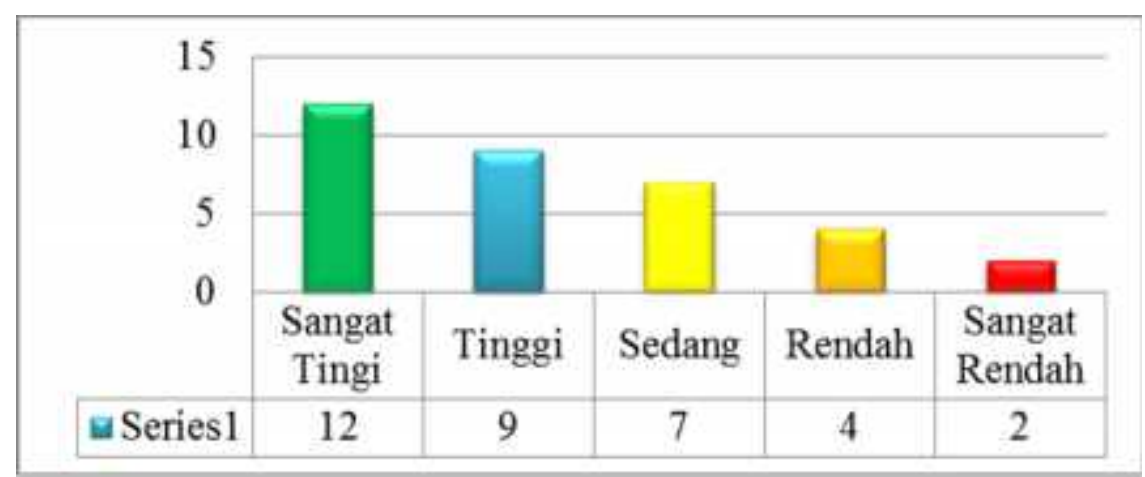

Diagram 2. Hasil Instrument Kemampuan Perencanaan Karier Siklus II

Berdasarkan gambar diagram batang di atas dimaknai bahwa siswa memiliki kemampuan perencanaan karier pada siklus II sebagai berikut, siswa berkemampuan perencanaan karier sangat tinggi terdiri dari 12 orang atau 35,29\%, siswa memiliki kemampuan perencanaan karier tinggi terdiri dari 9 orang atau 26,47\%, siswa memiliki kemampuan perencanaan karier sedang sebanyak 7 orang 20,59\%, siswa memiliki kemampuan perencanaan karier rendah sebanyak 4 orang atau $11,76 \%$ dan siswa memiliki disiplin belajar sangat rendah sebanyak 2 orang atau $5,88 \%$.

\section{Pembahasan}

Penelitian ini dilaksanakan sesuai dengan prosedur Penelitian Tindakan Bimbingan dan Konseling yang telah ditetapkan dari awal dengan perencanaan, pelaksanaan tindakan, observasi, dan evaluasi yang dilanjutkan dengan refleksi. Tahap perencanaan siklus I dan II yang dilakukan adalah menyiapkan rencana program kegiatan, lembar observasi untuk mencatat aktivitas guru dan aktivitas siswa sebagai salah satu penentu indikator keberhasilan, memahami materi kegiatan layanan informasi karier dalam meningkatkan kemampuan perencanaan karier pada saat pandemi Covid-19.

Berdasarkan hasil analisis data pelaksanaan tindakan pada siklus I menunjukkan bahwa prosentase kemampuan perencanaan karier kategori sangat tinggi sebanyak 4 orang atau $11,76 \%$, kemampuan perencanaan karier tinggi sebanyak 5 orang atau $14,71 \%$, sedang sebanyak 8 orang atau $23,53 \%$, rendah 8 orang sebesar $23,53 \%$ dan kemampuan perencanaan karier kategori sangat rendah 9 orang atau 26,47\%. Hal ini disebabkan oleh:

1) Masih ada siswa kurang antusias menerima layanan informasi karier pada saat pandemi Covid-19.

2) Guru masih kurang optimal dalam mengikuti layanan informasi karier.

3) Kurangnya interaksi siswa denga guru.

4) Siswa kurang aktif dalam mengeluarkan pendapat dan menyimpulkan hasil layanan informasi karier saat pandemi Covid-19. 
Sedangkan berdasarkan hasil analisis siklus II diperoleh siswa memiliki kemampuan perencanaan karier sangat tinggi sebanyak 12 orang atau 35,29\%\%, kemampuan perencanaan karier tinggi sebesar 9 orang atau 26,47\% dan kemampuan perencanaan karier kategori sedang sebesar 7 orang atau 20,59\%, kemampuan perencanaan karier rendah sebanyak 4 orang atau $11,76 \%$, dan kemampuan perencanaan karier sangat rendah sebanyak 2 orang atau $5,88 \%$.

Tabel 1. Perbandingan Nilai Hasil Kemampuan Perencanaan Karier Saat Pandemi Covid-19 Kelas XII-MIA-1 SMA Negeri 2 Praya

\begin{tabular}{|l|l|l|l|}
\hline No & \multicolumn{1}{|c|}{ Aspek } & Hasil siklus I & Hasil siklus II \\
\hline 1. & Jumlah siswa bimbingan & 34 orang & 34 orang \\
\hline 2. & Perencanaan karier sangat tinggi & 4 & 12 \\
\hline 3. & Perencanaan karier tinggi & 5 & 9 \\
\hline 4. & Perencanaan karier sedang & 8 & 7 \\
\hline 5. & Perencanaan karier rendah & 8 & 4 \\
\hline 6. & Perencanaan karier sangat rendah & 9 & 2 \\
\hline
\end{tabular}

Dari data tersebut dapat dilihat bahwa apabila layanan informasi karier meningkat maka perencanaan karierpun meningkat sehingga telah mencapai indikator keberhasilan yang ditetapkan. Grafik peningkatan kemampuan perencanaan karier siswa dapat digambarkan sebagai berikut.

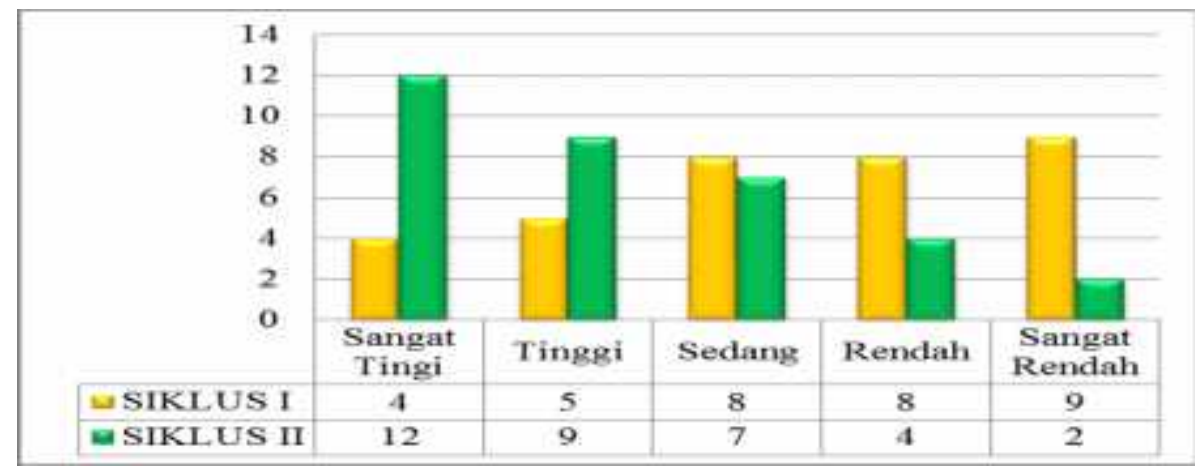

\section{Diagram 3. Perbandingan Nilai Hasil Kemampuan Perencanaan Karier Pada Saat Pandemi Covid-19 Kelas XII-MIA-1 SMA Negeri 2 Praya}

Berdasarkan diagram di atas menggambarkan terjadi peningkatan kemampuan perencanaan karier pada saat pandemi Covid-19 pada siklus II.

\section{Kesimpulan}

Kesimpulan yang diperoleh dari hasil penelitian ini adalah berdasarkan hasil analisis data pelaksanaan tindakan pada siklus I menunjukkan bahwa prosentase kemampuan perencanaan karier kategori siswa sangat tinggi sebanyak 4 orang atau 11,76\%, kemampuan perencanaan karier tinggi sebanyak 5 orang atau $14,71 \%$, sedangkan sebanyak 8 orang atau $23,53 \%$, rendah 8 orang sebesar 23,53\% dan kemampuan perencanaan karier kategori sangat rendah 9 orang atau 26,47\%. Berdasarkan hasil analisis siklus II diperoleh siswa memiliki kemampuan perencanaan karier sangat tinggi sebanyak 12 orang atau 35,29\%\%, kemampuan perencanaan karier tinggi sebesar 9 orang atau 26,47\% dan kemampuan perencanaan karier kategori sedang sebesar 7 orang atau 20,59\%, kemampuan perencanaan karier rendah sebanyak 4 orang atau $11,76 \%$, dan kemampuan perencanaan karier sangat rendah sebanyak 2 orang atau $5,88 \%$. 


\section{Saran}

Adapun saran yang dapat disampaikan berdasarkan hasil penelitian ini antara lain adalah (1) Bagi konselor, hendaknya dalam memberikan layanan informasi karier lebih bervariatif dan meningkatkan frekuensi pemberian layanan informasi karier untuk membantu siswa dalam membuat perencanaan kariernya dengan membimbing dan memberikan informasi-informasi yang relevan melalui layanan informasi karier. (2) Bagi sekolah, hendaknya memfasilitasi konselor yang bertugas agar memperdalam dan mengembangkan layanan Bimbingan Konseling khususnya layanan informasi karier.

\section{Daftar Pustaka}

Arifin, Z. (2012). Evaluasi Pembelajaran. Jakarta : Direktorat Jenderal Pendidikan Islam Kementerian Agama RI.

Ifdil. (2011). Pengertian Karier. Online. Tersedia di http://konselingindonesia.com/index.php?option=com_content\&task=view\&i $\mathrm{d}=222 \&$ Itemid=148 [diakses 6 Oktober 2017]

Hurlock, E. B. (2012). Psikologi Perkembangan, Suatu Pendekatan Sepanjang Rentang Kehidupan (terjemahan). Jakarta: Erlangga.

Mugiarso, Heru, dkk. (2009). Bimbingan dan Konseling. Semarang: UPT MKK UNNES

Mulyadi, Widi. (2011). Pengaruh Kemampuan Karyawan Terhadap Kinerja Karyawan pada Cabang Toko Top Fashion Cimahi.

Munandir. (1996). Program Bimbingan Karier di Sekolah. Jakarta: Departemen Pendidikan dan Kebudayaan Direktorat Jendral Pendidikan Tinggi pendidikan. Yogyakarta: Media Abadi.

Prayitno dan Erman Amti. (2004). Dasar-Dasar Bimbingan dan Konseling. Jakarta: PT Rineka Cipta

Serikandi, B. (2020). Upaya Meningkatan Motivasi Belajar Siswa Melalui Layanan Bimbingan Kelompok di Kelas XII-IIS-1 SMA Negeri 1 Pujut. Jurnal Paedagogy, 7(2), 78-89. doi:https://doi.org/10.33394/jp.v7i2.2498

Sugiyono. (2010). Statistik untuk Penelitian. Bandung: Alfabeta

Supriatna, Mamat. (2009). Bimbingan Karier di SMK. dalam bentuk e-book

Suryani, O., \& Gunawan, I. (2018). Hubungan Pemahaman Diri dengan Sikap Percaya Diri Pada Siswa Kelas VIII SMPN 7 Woja. Jurnal Kependidikan: Jurnal Hasil Penelitian dan Kajian Kepustakaan di Bidang Pendidikan, Pengajaran dan Pembelajaran, 4(2), 188-191. doi:https://doi.org/10.33394/jk.v4i2.1128

Ummah, M. (2013). Penerapan Layanan Informasi Karier untuk Meningkatkan Kemampuan Perencanaan Karier Siswa Kelas XII SMAN I Krembung Sidoarjo. Jurnal BK UNESA, 1(1).

Zultoni, J., \& Herna Astuti, F. (2020). PENGARUH LAYANAN KONSELING INDIVIDU TERHADAP PENYESUAIAN DIRI SISWA DI SMAN 2 PRINGGARATA. Jurnal Paedagogy, 3(2), 45-51. doi:https://doi.org/10.33394/jp.v3i2.3036 